\title{
Comparing the effects of glazing and chitosan-based coating applied on frozen salmon on its organoleptic and physicochemical characteristics over six-months storage
}

\author{
N. Soares a , P. Silva a , C. Barbosa ${ }^{\text {b, c }}$, R. Pinheiro ${ }^{\text {a, b }}$, A.A. Vicente ${ }^{\text {a, * }}$ \\ ${ }^{a}$ Centre for Biological Engineering, Universidade do Minho, Campus de Gualtar, 4710-057, Braga, Portugal \\ ${ }^{\mathrm{b}}$ IPVC-ESTG (Polytechnic Institute of Viana do Castelo - Escola Superior de Tecnologia e Gestão), Viana do Castelo, Portugal \\ ${ }^{\mathrm{c}}$ LAQV-REQUIMTE, Faculty of Pharmacy, University of Porto, Porto, Portugal
}

\section{A R T I C L E I N F O}

\section{Article history:}

Received 17 March 2016

Received in revised form

15 June 2016

Accepted 31 July 2016

Available online 31 August 2016

\section{Keywords:}

Salmon

Chitosan

Anti-microbiological

Flavor diffusion

Sensory analysis

\begin{abstract}
A B S T R A C T
The perishable nature of fish, with an increase in fish consumption in recent years, led to the improvement of fish preservation techniques. Chitosan coatings adds to the traditional water glazing.

The effect of a chitosan solution of $1.5 \%$ on the sensory properties of Atlantic salmon (Salmo salar) was studied over six months of storage. The sensory properties of the salmon were assessed through the use of a texturometer and a trained panel of judges. Microbiological parameters were studied in the form of Total Volatile Base Nitrogen (TVB-N) and Total Viable Count (TVC) tests.

Microbiological analysis showed that chitosan had an anti-microbiological effect on the salmon samples, reducing the number of microorganisms present, while TVB-N values were maintained stable during experiment.

Textural Profile Analysis (TPA) was performed and the results showed no significant differences between different coatings regarding texture. Sensory analysis by a trained panel showed that chitosan was a better choice in frozen samples, while in thawed and cooked samples no significant differences existed between chitosan-coated and glazed samples. Flavor diffusion from the chitosan coating was assessed, and analysis of the results showed no correlation between coating type and sample flavor, indicating that no flavor diffusion had occurred.
\end{abstract}

(c) 2016 Elsevier Ltd. All rights reserved.

\section{Introduction}

The consumption of fish has been steadily increasing over the last few years, due to its nutritional characteristics as well as for its benefits to the health of the consumers. According to the latest publication from the Department of Food and Agriculture Organization of the United Nations (FAO), the total amount of world fisheries has been increasing over the past decades with the use of fish for food purposes increasing at an average annual rate of 3.2\% (FAO, 2014).

Fresh fish is among the most perishable foods due to some intrinsic characteristics of fish, such as its lipid content, due to microbiological changes in the fish, and also due to external factors such as temperature and exposure time before preservation

\footnotetext{
* Corresponding author.

E-mail address: avicente@deb.uminho.pt (A.A. Vicente).
}

methods are applied (Huss, 1995). Thereby the improvement in preservation techniques in order to bring the fish product in a safely manner to the consumer, while maintaining its organoleptic characteristics, are a major concern of this industry. In the fishing industry the most widely used are freezing and glazing. Freezing represents the main method of preservation for human consumption and inhibits enzymatic activities, slowing down the growth of microorganisms and reducing the microbial metabolism responsible for the deterioration (González-Méndez et al., 2004; Nielsen and Jessen, 2007).

Glazing is largely used in the fish industry to protect fish from the deterioration of sensory characteristics, and can be defined as the application of a layer of ice in frozen products surface by means of a dipping process, or by spraying in a water bath (Zoldos et al., 2011). Glazing is still the less expensive protection technology, having thus became a widely used process in the fish industry.

An edible coating or film can be defined as primary packaging prepared from edible components. In this type of packaging a thin 
layer of edible material can be directly applied to a food or formed into a film and used as a food wrap (Pascall and Lin, 2012).

Chitosan can be used as an edible coating or film and is one of the most important derivatives of chitin. Chitosan can be defined as a copolymer that is composed by $\mathrm{N}$-acetyl-D-glucosamine and Dglucosamine units, which can be distributed throughout the biopolymer either randomly or in blocks, these units are combined by $\beta-(1,4)$ glucosidic linkages thus forming a long chain linear polymer (Castro and Paulín, 2012; Chen, 2008; Singh and Kumari, 2012). Chitosan is a biomolecule with great potential, presenting properties such as biocompatibility and biodegradability, together with its anti-viral, anti-fungal and anti-microbial activities (Kim, 2014). However it is necessary to assure that no organoleptic changes occur due to the presence of the chitosan coating, so sensory analysis is needed to ensure the possibility of use of chitosan coatings.

Among the sensory testing methods available to assess fish freshness, Quantitative Descriptive Analysis (QDA) allows obtaining a detailed description of organoleptic characteristics present in the product assessed in a quantitative way. Judges are given a wide selection of reference samples and use the samples in order to define a terminology that accurately describes the product in question (Lawless and Heymann, 2010).

The objective of this work was assess the sensory (using QDA) and physico-chemical effects of a chitosan coating on frozen salmon samples over a six month period and compare them with water glazed samples under the same conditions.

\section{Materials and methods}

\subsection{Fish preparation}

Frozen Atlantic salmon (Salmo salar) supplied by the company Vanibru - Comércio de produtos alimentares, Braga, Portugal) was used. Each salmon was cut into several pieces, with about $2 \mathrm{~cm}$ of thickness, using a vertical bone sawing machine (FK 32, BIZERBA, Germany). This process was carried out in a refrigerated room (with temperature between $5{ }^{\circ} \mathrm{C}$ and $8{ }^{\circ} \mathrm{C}$ ) in order to reduce the heat uptake and the corresponding temperature fluctuation. The samples were separated according to the intended use and intended coating and stored in plastic bags in an industrial freezing chamber $\left(-25^{\circ} \mathrm{C}\right)$ until further use or transportation.

\subsection{Coating solutions}

The chitosan solutions used were prepared using chitosan from Golden-shell Biochemical Co. Ltd. (China) with a 91\% degree of deacetylation. In a $5 \mathrm{~L}$ Erlenmeyer a $2 \mathrm{~L}$ solution of chitosan $(1.5 \%$ $(\mathrm{w} / \mathrm{v})$ (Soares et al., 2016)) was prepared dissolving $30 \mathrm{~g} \pm 0.01 \mathrm{~g}$ with $22.2 \mathrm{~mL}$ of a $1 \%$ lactic acid solution ( $90 \%(\mathrm{w} / \mathrm{w})$ purity) and the volume was completed up to $2 \mathrm{~L}$ with distilled water. The solution was stirred with a magnetic stirrer in a heating plate (VWR; Model: VMS-C7 Advanced) at $70{ }^{\circ} \mathrm{C}$, until complete dissolution of the chitosan. The temperature was then turned off and the solution remained in agitation overnight. The solution was then transferred to a closed glass container and stored at $8{ }^{\circ} \mathrm{C}$.

\subsection{Sample preparation}

Samples of frozen salmon were removed from the industrial freezing chamber and were weighed (RADWAG WLC 6/A2/C/2, Poland), and dipped in a $1.5 \%(\mathrm{w} / \mathrm{v})$ chitosan solution at $8{ }^{\circ} \mathrm{C}$ (measured using an infrared Pronto Plus thermometer (HANNA Instruments, HI99556-10, Romania) with the respective probe (HANNA Instruments, HI765PW, Romania)) during $10 \mathrm{~s}$ and then drained for $2 \mathrm{~min}$, before being weighed again and stored in the industrial freezing chamber until further use. The dipping process was performed in a pilot-scale glazing tank, previously built for this effect, with the help of a stainless steel mesh used to hold the fish. The salmon samples intended for water glazing were weighed before dipping in water for $40 \mathrm{~s}$ and then drained for $1 \mathrm{~min}$, before being weighed again and stored in an industrial freezing chamber until further use (Soares et al., 2016). The dipping process was performed with the pilot-scale glazing tank and mesh mentioned above. The control samples did not require any additional treatment other than the cutting of the salmon and storage in an industrial freezing chamber.

\subsection{Samples storage and transport}

The salmon samples were stored in polyethylene bags and separated by coating in different corrugated boxes.

Samples intended for sensory analysis were transported by a freezer truck to the Instituto Politécnico de Viana de Castelo Escola Superior de Tecnologia e Gestão (IPVC-ESTG) facilities, where all of the sensory tests were performed, and where they were maintained at $-18{ }^{\circ} \mathrm{C}$ until further use. The samples used for the microbiological tests were maintained in an industrial freezing chamber set to $-18{ }^{\circ} \mathrm{C}$ until they were sent for microbiological analysis.

\subsection{Samples analyses}

\subsubsection{Percentage of glazing or coating}

In order to calculate the percentage of glazing or coating, the salmon pieces were weighed before $\left(W_{\text {salmon }}\right)$ and after $\left(W_{i}\right)$ being dipped. Percentage of glazing or coating was then calculated using Equation (1).

$\%$ Glazing $=\frac{W i-\text { Wsalmon }}{W i} 100$

\subsubsection{Determination of total volatile based nitrogen (TVB-N)}

The TVB-N values for coated and uncoated samples were determined by the Conway method, as referenced in the NP 2930:2009 standard (IPQ, 2009). The results for all salmon samples, coated or uncoated, were expressed in $\mathrm{mg}$ of nitrogen per $100 \mathrm{~g}$ of sample.

\subsubsection{Determination of Total Viable Count}

The determination of Total Viable Count was estimated and performed according to the procedure based on the ISO 48331:2013 standard (ISO, 2013). Samples of coated salmon, glazed salmon, and uncoated salmon were analyzed in quadruplicate. The results were reported as the number of log of microorganisms per gram of sample.

\subsubsection{Determination of texture}

Texture was assessed using a texturometer (TA.XT plus Texture Analyser, Stable Micro Systems Ltd.) equipped with a $10 \mathrm{~mm}$ diameter cylinder DELRIN probe. A texture profile analysis (TPA) was performed on salmon samples (thawed and cooked chitosan coated and water glazed). Each sample was tested at least in six points, for a minimum of 18 test points for each coating or glazing.

The parameters retained with this test were the peak positive force of the first cycles, the area to positive peak of the first and second cycles, and the distance (from the beginning to the maximum peak - obtained by manually marking in the 
texturometer exponent software the points from the beginning to the top of a peak) of the first and second cycles. With this information it was possible to calculate the parameters Hardness, Cohesiveness and Springiness (Texture Technologies Corporation, 2015).

The TPA setup for the raw samples and for the cooked samples were very similar (Test speed: $1 \mathrm{~mm} / \mathrm{s}$; Target mode: distance; Time: $2 \mathrm{~s}$ ), with the only difference being the distance that the probe travelled after impact, since cooking reduces the samples thickness. For raw samples it was defined $15 \mathrm{~mm}$ and for cooked samples $10 \mathrm{~mm}$.

\subsubsection{Sensory analysis}

2.5.5.1. Preparation of samples. The samples used for the sensory analysis were initially removed from the industrial freezing chamber at $-18{ }^{\circ} \mathrm{C}$ and immediately evaluated. After this samples were left to thaw during $18 \mathrm{~h}$ at $4{ }^{\circ} \mathrm{C}$, in two distinct ways: a) the coating was removed from the sample before thawing and $b$ ) the samples were placed inside individually marked zip-lock bags (with coating), and the coating was removed only after thawing. Cooked salmon samples were boiled in $2 \mathrm{~L}$ of water during $5 \mathrm{~min}$, and then left to cool down for $30 \mathrm{~min}$.

2.5.5.2. Procedure of analysis. Sensory quality evaluation was carried out performing a QDA test. An assessment sheet was previously developed by a seven judge trained panel of the IPVC-ESTG. Firstly the panel assessed frozen salmon samples, evaluating color, odor and overall appearance. After thawing samples were assessed regarding the parameters of color, odor, texture and general appearance. Lastly, cooked samples were assessed regarding four parameters, odor, texture, flavor and general appearance. All

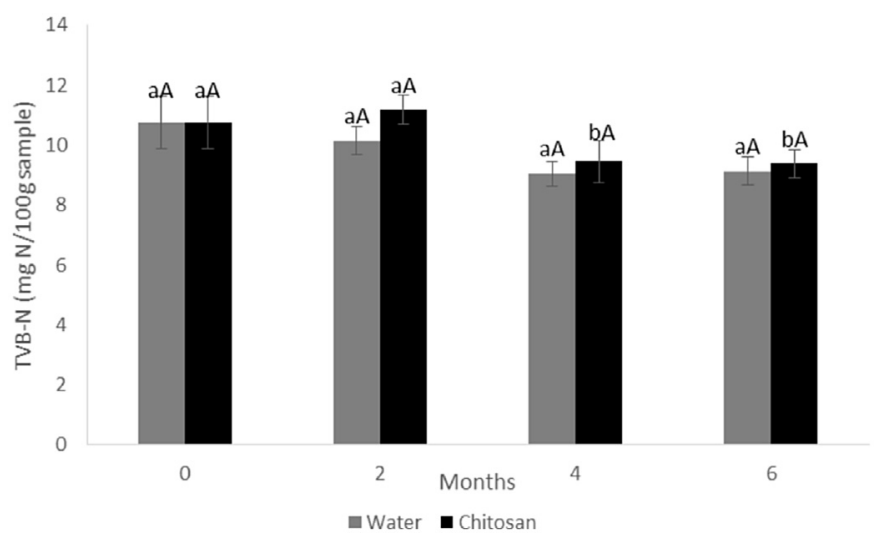

Fig. 1. TVB-N values for salmon samples during six months of storage at $-18{ }^{\circ} \mathrm{C}$; standard deviation corresponds to four replications; different small letters in the same sample type, and different capital letters in the same time moment indicate a statistically significant difference (Tukey HSD test, $\mathrm{p}<0.05$ ). samples were rated in a structured six-point scale ranging from correct to incorrect characteristics.

2.5.5.3. Statistical analysis. Experiments were performed at least in triplicate, and in some cases more. The mean values of those independent determinations were calculated for each treatment at every moment. The statistical significance of differences among treatment was evaluated by a factorial ANOVA test followed by the Tukey HSD test with significance at $p<0.05$. Principal component analysis (PCA) of sensory data was performed in order to find which parameters are important to discriminate samples. The samples are labeled by time and coating type, in order to provide a better distinction between different coatings and moments of assessment. Data were evaluated statistically using the software STATISTICA version 10.0 (StatSoft Inc. 2011).

\section{Results and discussion}

\subsection{Microbiological analysis}

\subsubsection{Percentage of glazing and coating uptake}

The percentages of glazing and coating uptake obtained for the samples used in the sensory analysis were $9.6 \pm 0.7 \%$ and $12.0 \pm 0.7 \%$ according to Equation (1). The values for glazing and coating percentages are in line with those reported in previous works, although higher percentages especially for chitosan were found (Soares et al., 2015).

\subsection{2. $T V B-N$}

In Fig. 1 it is possible to see the results of the TVB-N tests performed. The control sample presented a TVB-N value of $10.768 \pm 0.886 \mathrm{mg}$ of nitrogen/100 g. Although with a decreasing tendency, the samples coated with chitosan or glazed with water did not vary greatly throughout the six months of storage, and did not present statistically significant differences between them. After six months of storage water glazed samples present a value of $9.138 \pm 0.454 \mathrm{mg}$ of nitrogen $/ 100 \mathrm{~g}$, while chitosan coated samples present a value of storage of $9.378 \pm 0.453 \mathrm{mg}$ of nitrogen $/ 100 \mathrm{~g}$, lower than the control sample, and well below the $35 \mathrm{mg}$ nitrogen/ $100 \mathrm{~g}$ fish established as the acceptable limit for salmon by EU Directive 95/149 (Official Journal of the European Communities, 1995). The lack of variation in the TVB-N values, and the absence of an expected increase after three months of storage can be a result of the low temperature used in the test, and the initial quality and good condition of the salmon, which is supported by the low TVC values found in 3.1.3 (Gonçalves and Gindri Junior, 2009).

\subsubsection{TVC}

Table 1 presents the TVC values of the salmon samples used in sensory analysis and stored during six months in an industrial freezer set to $-20{ }^{\circ} \mathrm{C}$. TVC values, with the exception of the final

Table 1

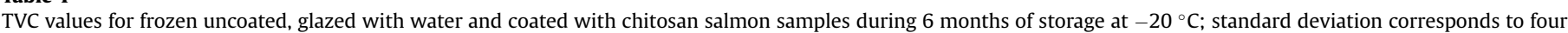

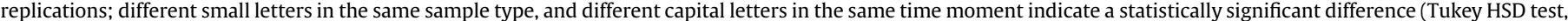
$\mathrm{p}<0.05)$.

\begin{tabular}{|c|c|c|c|c|c|c|c|}
\hline TVC $-20^{\circ} \mathrm{C}$ & Storage time (months) & Sample $1(\log$ CFU/g) & Sample $2(\log \mathrm{CFU} / \mathrm{g})$ & Sample $3(\log$ CFU/g) & Sample $4(\log$ CFU/g) & Mean $(\log$ CFU/g) & SD \\
\hline Control samples & 0 & $2.146^{\mathrm{aA}}$ & $2.431^{\mathrm{aA}}$ & $2.64^{\mathrm{aA}}$ & $2.875^{\mathrm{aA}}$ & $2.602^{\mathrm{aA}}$ & 2.421 \\
\hline \multirow[t]{3}{*}{ Water Glazed samples } & 2 & $2.909_{\mathrm{aA}}$ & $2.994^{\mathrm{aA}}$ & $2.681^{\mathrm{aA}}$ & $2.978^{\mathrm{aA}}$ & $2.892^{\mathrm{aA}}$ & 2.318 \\
\hline & 4 & $3.079_{\mathrm{aA}}$ & $3.000^{\mathrm{aA}}$ & $3.079^{\mathrm{aA}}$ & $3.176^{\mathrm{aA}}$ & $3.088^{\mathrm{aA}}$ & 2.314 \\
\hline & 6 & $2.806^{\mathrm{aA}}$ & $2.756^{\mathrm{aA}}$ & $2.724^{\mathrm{aA}}$ & $2.949^{\mathrm{aA}}$ & $2.818^{\mathrm{aA}}$ & 2.208 \\
\hline \multirow[t]{3}{*}{ Chitosan Coated samples } & 2 & $2.663^{\mathrm{aA}}$ & $2.362^{\mathrm{aA}}$ & $2.146^{\mathrm{aA}}$ & $<1.000^{\mathrm{bB}}$ & $2.442^{\mathrm{aA}}$ & 2.278 \\
\hline & 4 & $<1.000^{\mathrm{bB}}$ & $2.041^{\mathrm{aB}}$ & $<1.000^{\mathrm{bB}}$ & $<1.000^{\mathrm{bB}}$ & - & - \\
\hline & 6 & $<1.000^{\mathrm{bB}}$ & $2.079^{\mathrm{aB}}$ & $2.000^{\mathrm{aB}}$ & $<1.000^{\mathrm{bB}}$ & - & - \\
\hline
\end{tabular}




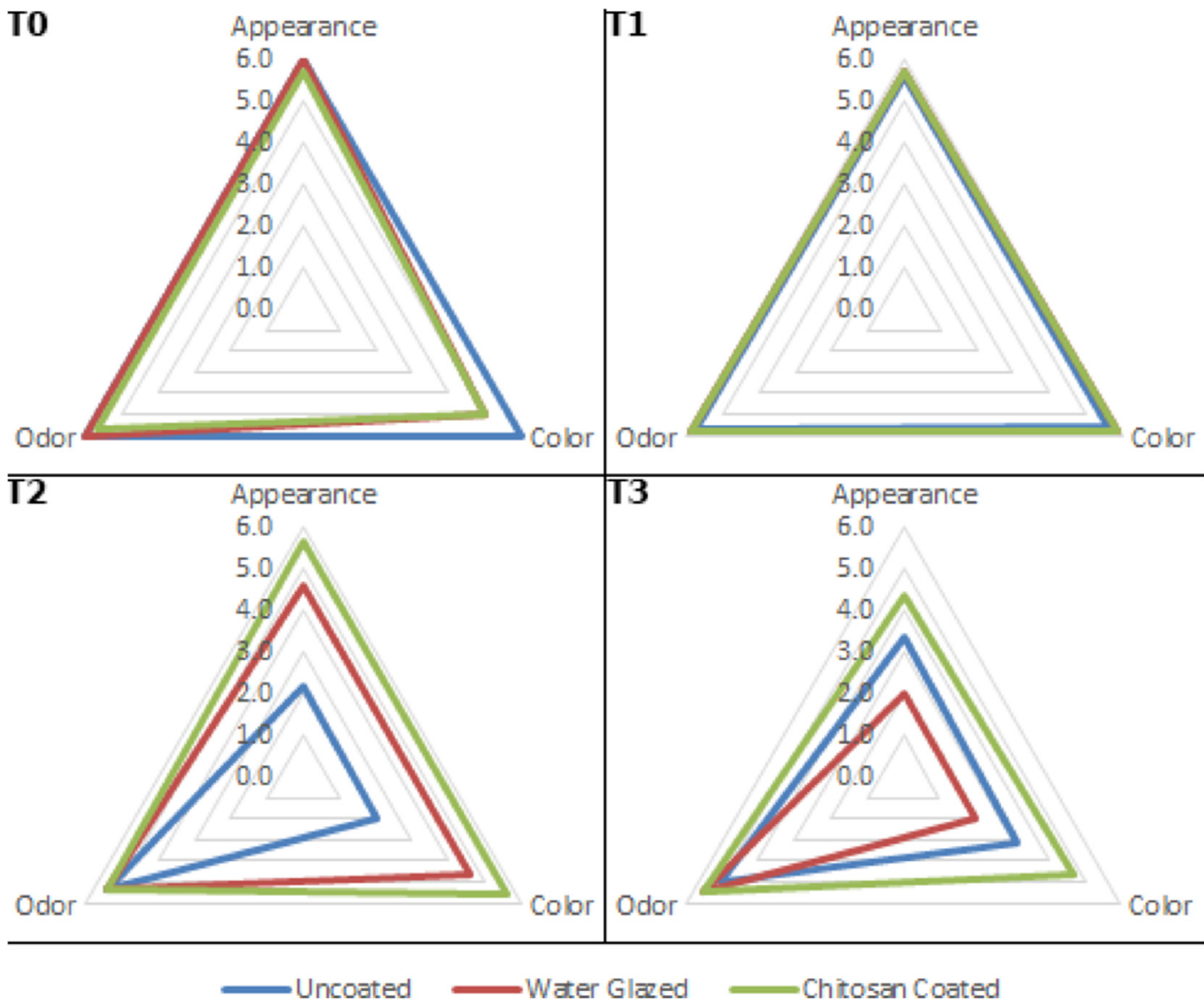

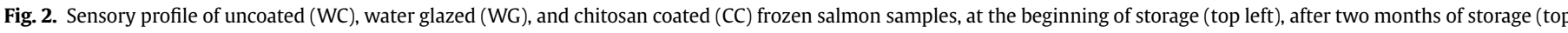
right), four months of storage (bottom left) and six months of storage (bottom right) at $-20{ }^{\circ} \mathrm{C}$.

value of the water glazed samples, increase with storage time, remaining at all times clearly higher than the TVC values of the chitosan coated samples, achieving the highest value of $3.176 \mathrm{log}$ $\mathrm{CFU} / \mathrm{g}$ after four months, and finishing with a value of $2.949 \mathrm{log}$ $\mathrm{CFU} / \mathrm{g}$ after six months. Chitosan coated samples clearly present the best results at all moments, with several of the samples being below the detectable value of the test (below $1 \log \mathrm{CFU} / \mathrm{g}$ ). This data on chitosan confirms ability of chitosan coatings to reduce microorganisms on food surfaces, that has been referenced by several authors over past years (Castro and Paulín, 2012; Raafat and Sahl, 2009; Rabea et al., 2003). Despite the long duration of the test, the TVC values are well below both the maximum limit of 7 log CFU/g for sensory detection and rejection (Olafsdóttir et al., 1997) and the microbiological limit of $5 \log$ CFU/g for quality frozen fish (International Commission on Microbiological Specifications for Foods, 1986).

\subsection{Sensory analysis}

\subsubsection{Frozen samples}

In Fig. 2, the sensory profiles of uncoated, water glazed and chitosan coated samples in frozen state are shown for all moments of testing.

Fig. 2 shows that in the first two months of storage (T0 and T1) differences between the samples were negligible. On the other hand, for the time periods of four (T2) and six months (T3), differences become more pronounced, being water glazed and uncoated samples less rated, clearly indicating that, in the frozen

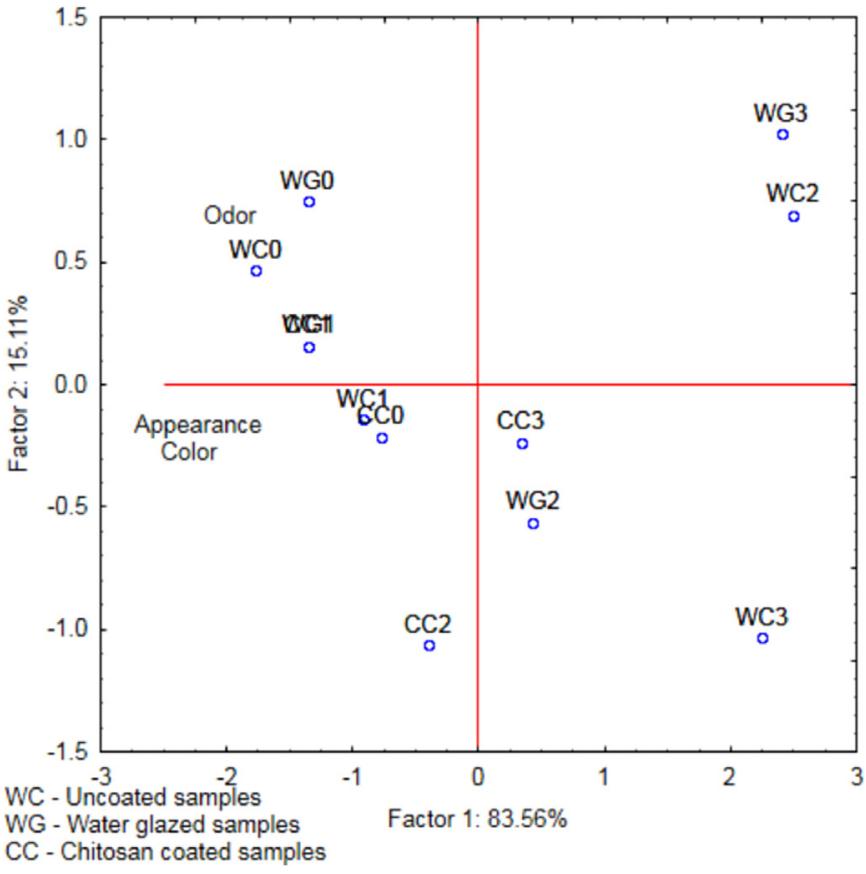

Fig. 3. Case projection after PCA analysis for the frozen salmon samples. 
Table 2

Factor-variable correlations after PCA analysis and Eigenvalues for frozen salmon samples.

\begin{tabular}{|c|c|c|c|c|c|c|c|}
\hline & & Odor & Color & Appearance & Texture & Flavor & Eigenvalues \\
\hline \multirow[t]{2}{*}{ Frozen samples } & Factor 1 & -0.818 & -0.952 & -0.965 & - & - & 2.507 \\
\hline & Factor 2 & 0.575 & -0.274 & -0.218 & - & - & 0.453 \\
\hline \multirow[t]{2}{*}{ Thawed samples } & Factor 1 & -0.939 & -0.966 & -0.963 & -0.943 & - & 3.633 \\
\hline & Factor 2 & 0.254 & -0.220 & -0.236 & 0.213 & - & 0.214 \\
\hline \multirow[t]{2}{*}{ Cooked samples } & Factor 1 & -0.933 & - & -0.836 & -0.879 & -0.900 & 3.152 \\
\hline & Factor 2 & 0.299 & - & -0.465 & 0.417 & -0.286 & 0.561 \\
\hline
\end{tabular}

state, chitosan coating preserved better all the parameters evaluated.

The results of the principal component analysis (Fig. 3) for frozen samples summarizes $98.67 \%$ of the information. Factor 1 represents $83.56 \%$ of the samples variation, while Factor 2 represents $15.11 \%$ of that variation. This means, also according to the Eigenvalues associated with each factor (Table 2) that only Factor 1 is relevant to explain differences between samples.

In PCA plot, it is possible to see that the chitosan coated samples follow a similar distribution to the other samples, which indicates that no changes occurred due to the type of coating used in the samples; it is also possible to see on Factor 1 axis that the chitosan coated samples present better results until the end of the study, especially when compared to the samples without any coating
(WC). A clear pattern that is seen is that the samples assessed after four (T2) and six months (T3) tend to stand out from the rest of the samples, indicating that concerning color, appearance and odor, chitosan coated samples (CC) have better results. This is supported by the findings in the sensory analysis profiles of Fig. 2, where the four and six months' samples present overall lower scores when compared to samples from earlier moments of assessment. With Factor 1 being responsible for the most part of the variation (Eigenvalue $>1$, in Table 2), through the factor-variable correlation it is possible to see that the color and appearance parameters are the ones causing higher differences between samples.

\subsubsection{Thawed samples}

Concerning thawed samples sensory analysis, results are

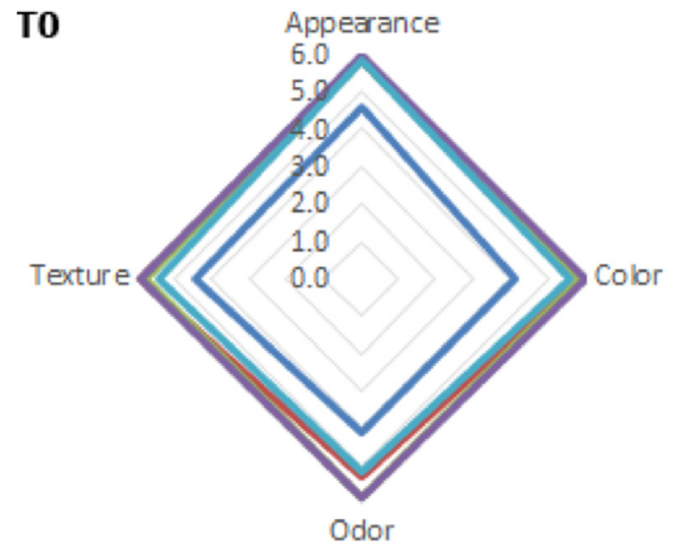

T2 Appearance

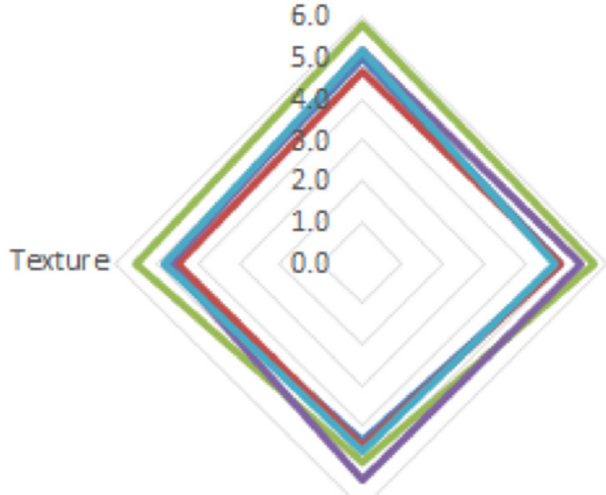

Odor
T1 Appearance

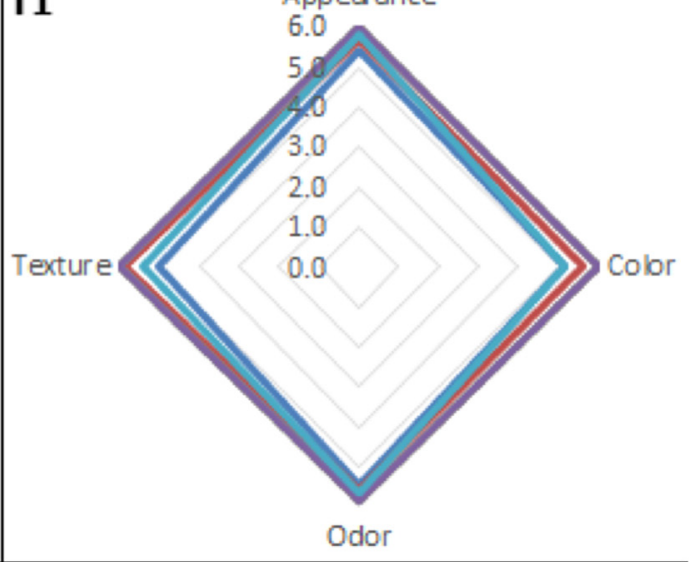

T3

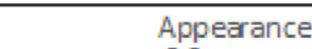

6.0

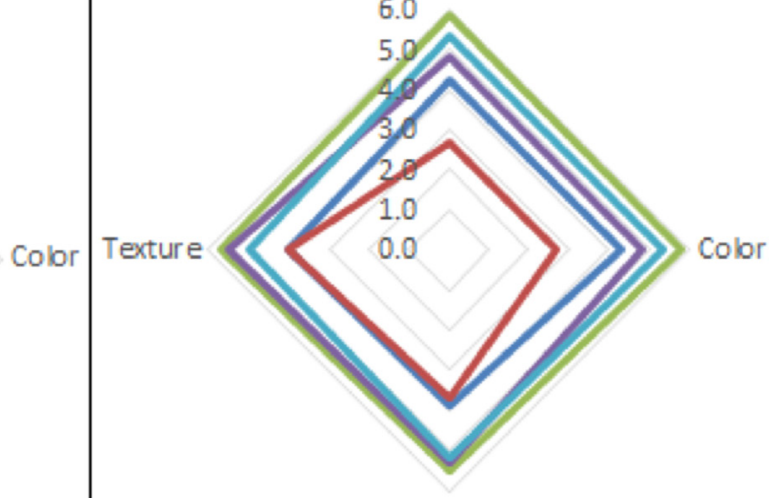

Odor

Chitosan Thawed Uncoated

Water Glazed

Water Thawed

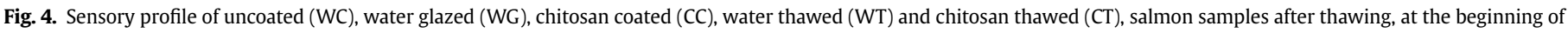
storage (top left), after two months of storage (top right), four months of storage (bottom left) and six months of storage (bottom right) at $-20{ }^{\circ} \mathrm{C}$. 


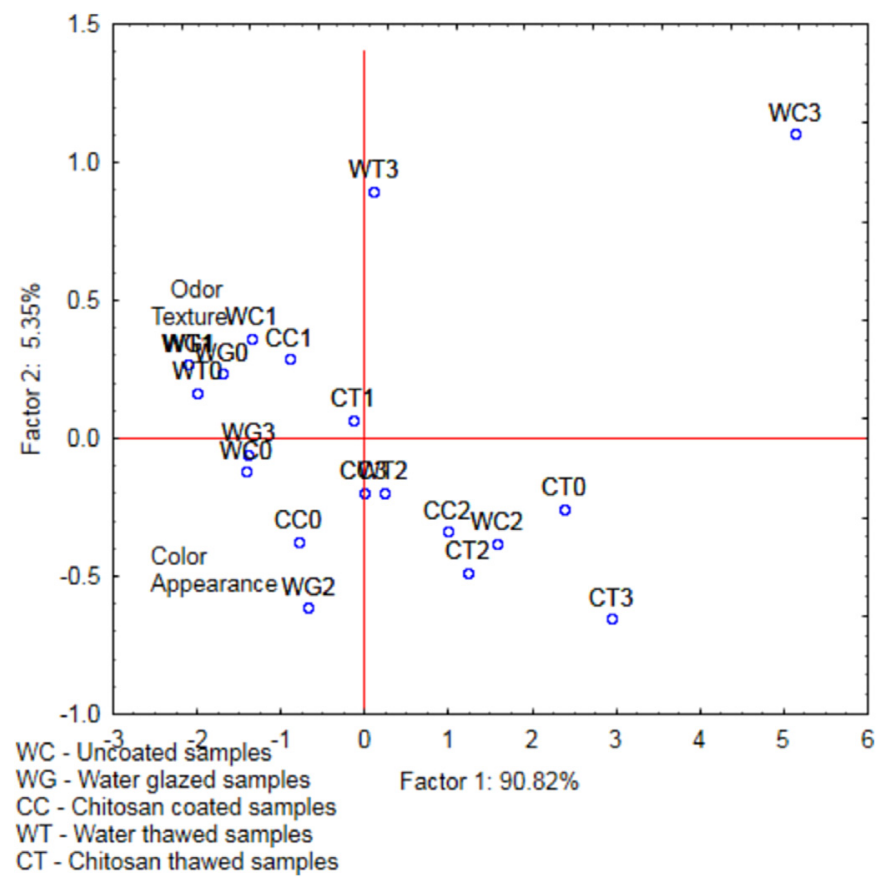

Fig. 5. Case projection after PCA analysis for the thawed salmon samples. presented in Fig. 4 it can be seen that in the first four months of storage, differences between the samples were also negligible, with the exception of chitosan thawed samples, which may be due to the extra handling needed for the removal of the coating. On the other hand, after six months of storage, differences become more pronounced, with the water glazed and the chitosan coated samples having the best results compared to uncoated samples (WC) in judges opinion.

PCA with thawed samples data summarizes $96.17 \%$ of the information (Factor 1 responsible for $90.82 \%$ and Factor 2 responsible for 5.35\%). With Factor 1 being responsible for the most part of the variation (Eigenvalue $>1$, in Table 2 ), through the factor-variable correlation is possible to see that all assessed parameters have a similar impact in the existing differences between samples.

In Fig. 5 it is possible to see that the chitosan coated samples follow a similar distribution as the other samples, which indicates that no significant changes were perceived by judges. The exceptions are the chitosan thawed and the uncoated samples assessed after six months (T3), which are distanced from the rest of the samples, indicating that they are clearly different, and in this case worse than the samples assessed at other times (as can be seen in plot T3 of Fig. 4 revealing lower scores), which supports the findings in the sensory analysis, where the six months' samples present overall lower scores when compared to samples from earlier

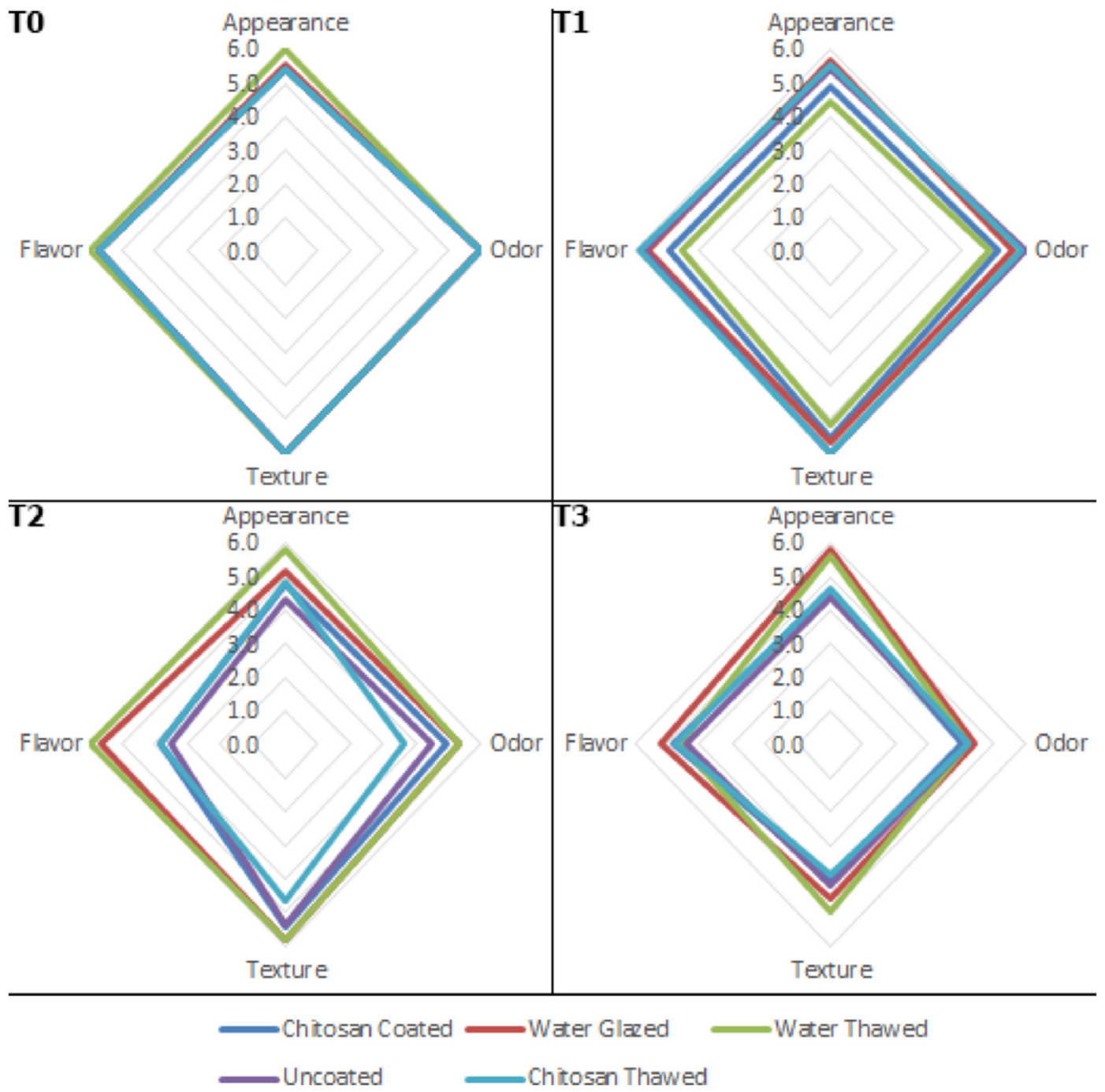

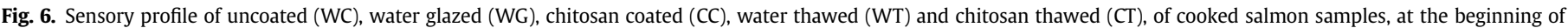
storage (top left), after two months of storage (top right), four months of storage (bottom left) and six months of storage (bottom right) at $-20{ }^{\circ} \mathrm{C}$. 


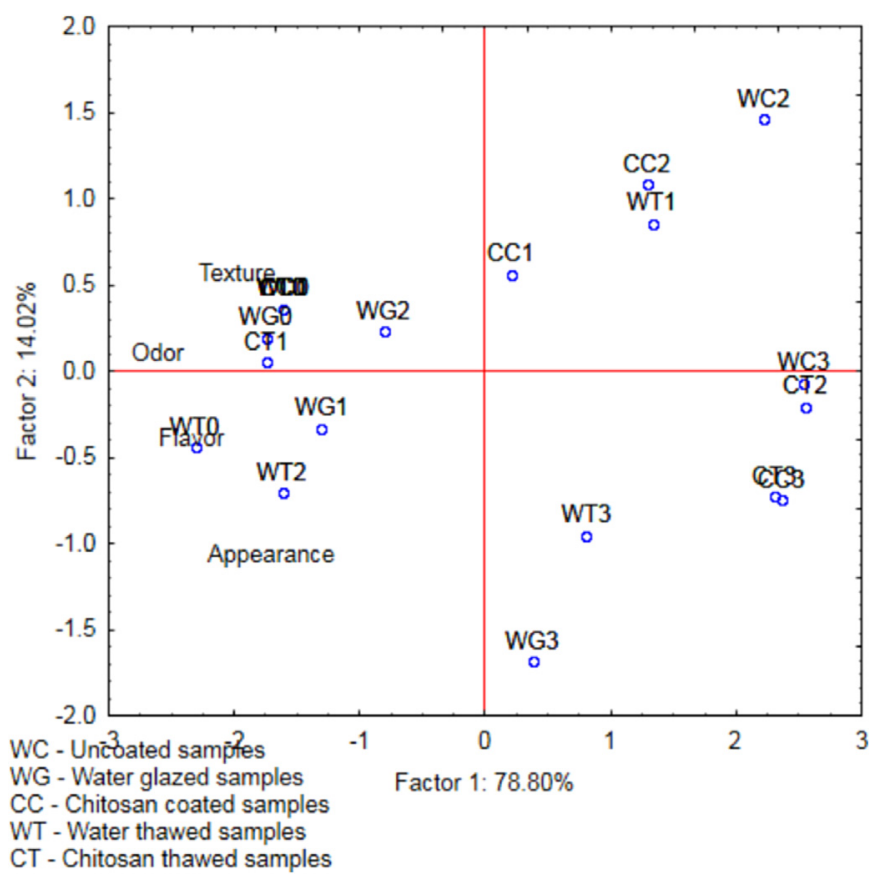

Fig. 7. Case projection after PCA analysis for the cooked salmon samples.

moments of assessment as seen in Fig. 4.

\subsubsection{Cooked samples}

In Fig. 6 the sensory profiles of uncoated, water glazed, chitosan coated, water thawed and chitosan thawed samples after cooking are shown for all moments of testing.

Fig. 6 shows that in the first two months of storage (plots T0 and T1) differences between the samples were not significant. For the last two moments of evaluation differences are more evident. This difference is more pronounced in the case of flavor and appearance evaluation of samples with 4 months of storage. In spite of chitosan coated and chitosan thawed samples having a slight overall lower rating on appearance characteristics, in flavor and odor parameters samples have similar rating than those of the water glazed and water thawed samples. Thus suggesting that the perceived differences are due to storage time and not so caused by coating aroma diffusion.

The results of the principal component analysis (Fig. 7) in the cooked samples data show that $92.82 \%$ of the variation is presented by Factor 1 and Factor 2, with Factor 1 being responsible for $78.80 \%$ of the samples variation, while Factor 2 summarizes $14.02 \%$ of that variation. Table 2 shows the Eigenvalues associated with each factor. In the plot it is possible to see that the chitosan coated (CC) samples tend to follow a similar distribution as the other samples, which confirms that no changes occurred due to the type of coating used in the samples. A pattern that is seen is that the samples of the later assessment moments tend to be further distanced from the main cluster of samples. With Factor 1 being responsible for the most part of the variation (Eigenvalue $>1$, in Table 2), through the factor-variable correlation is possible to see that the odor parameter has a higher impact in the existing differences between samples than the other parameters.

After analyzing sensory results from all type of studied coatings and stage of the processing (raw, thawed and cooked) it can be said that the studied organoleptic properties were not significantly affected by the use of chitosan coating. Samples were quite stable over time although some alteration in flavor and odor being pointed out by judges. This is an important achievement once they were initially not expected to be perceived by trained panelists.

\subsection{Texture analysis}

The textural properties of thawed and cooked salmon were assessed by a texture profile analysis, which allowed for the determination of the four parameters: hardness, cohesiveness, springiness and chewiness. The results for the thawed and cooked samples for these four parameters, during six months of storage at $-18{ }^{\circ} \mathrm{C}$ can be seen in Table 3. Despite the differences in process and handling between the water glazed and chitosan-coated samples due to difficulties in removing the chitosan coating from the samples, results do not vary significantly during the different time periods assessed nor between different coatings, for all of the parameters assessed. Although there is a slight difference between the raw and cooked samples, with the cooked samples having slightly lower values, which is to be expected given that the cooked samples suffer changes from the cooking process, among them the reduction of their thickness. The values of all parameters are similar to those found in other studies for thawed salmon with similar conditions, although slightly higher for all moments of evaluation, suggesting that this tendency is related to the samples, rather than the coatings applied (Casas et al., 2006; Hultmann and Rustad, 2004; Martinez et al., 2007). These results are in agreement with the outcome of the sensory analysis by the panel of judges

Table 3

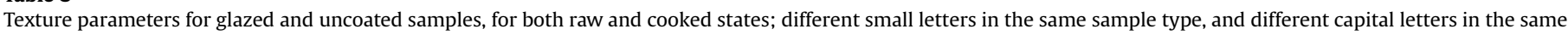
time moment indicate a statistically significant difference (Tukey HSD test, $\mathrm{p}<0.05$ ).

\begin{tabular}{|c|c|c|c|c|c|c|}
\hline Sample state & Time & Coating & Hardness & Cohesiveness & Springiness & Chewiness \\
\hline \multirow[t]{8}{*}{ Raw samples } & T0 & Glazing & $7.76^{\mathrm{aA}}$ & $0.39^{\mathrm{aA}}$ & $1.10^{\mathrm{abA}}$ & $3.86^{\mathrm{aA}}$ \\
\hline & T0 & Chitosan & $7.50^{\mathrm{aA}}$ & $0.38^{\mathrm{aA}}$ & $1.10^{\mathrm{aA}}$ & $3.35^{\mathrm{aA}}$ \\
\hline & $\mathrm{T} 1$ & Glazing & $6.05^{\mathrm{bA}}$ & $0.39^{\mathrm{aA}}$ & $1.13^{\mathrm{abA}}$ & $2.68^{\mathrm{bA}}$ \\
\hline & $\mathrm{T} 1$ & Chitosan & $6.33^{\mathrm{abA}}$ & $0.34 \mathrm{a}^{\mathrm{bA}}$ & $1.02^{\mathrm{aA}}$ & $2.38^{\mathrm{bA}}$ \\
\hline & $\mathrm{T} 2$ & Glazing & $6.47^{\mathrm{abA}}$ & $0.31^{\mathrm{bA}}$ & $1.05 \mathrm{a}^{\mathrm{bA}}$ & $2.92^{\mathrm{bA}}$ \\
\hline & $\mathrm{T} 2$ & Chitosan & $5.23^{\mathrm{bA}}$ & $0.32^{\mathrm{bA}}$ & $1.02^{\mathrm{aA}}$ & $1.96^{\mathrm{bB}}$ \\
\hline & T3 & Glazing & $6.09^{\mathrm{bA}}$ & $0.42^{\mathrm{aA}}$ & $1.19^{\mathrm{aA}}$ & $3.49^{\mathrm{abA}}$ \\
\hline & T3 & Chitosan & $6.90^{\mathrm{aA}}$ & $0.35^{\mathrm{abB}}$ & $1.07^{\mathrm{aB}}$ & $2.74^{\mathrm{abA}}$ \\
\hline \multirow[t]{8}{*}{ Cooked samples } & T0 & Glazing & $7.43^{\mathrm{aA}}$ & $0.29^{\mathrm{aA}}$ & $1.00^{\mathrm{aA}}$ & $2.36^{\mathrm{aA}}$ \\
\hline & T0 & Chitosan & $5.71^{\mathrm{aB}}$ & $0.30^{\mathrm{aA}}$ & $1.00^{\mathrm{aA}}$ & $1.71^{\mathrm{aA}}$ \\
\hline & $\mathrm{T} 1$ & Glazing & $6.88^{\mathrm{aA}}$ & $0.27^{\mathrm{aA}}$ & $1.01^{\mathrm{abA}}$ & $1.82^{\mathrm{aA}}$ \\
\hline & $\mathrm{T} 1$ & Chitosan & $6.31^{\mathrm{aA}}$ & $0.30^{\mathrm{abA}}$ & $1.00^{\mathrm{aA}}$ & $1.79^{\mathrm{aA}}$ \\
\hline & $\mathrm{T} 2$ & Glazing & $7.00^{\mathrm{aA}}$ & $0.27^{\mathrm{aA}}$ & $1.00^{\mathrm{aA}}$ & $1.84^{\mathrm{aA}}$ \\
\hline & $\mathrm{T} 2$ & Chitosan & $5.79^{\mathrm{aA}}$ & $0.30^{\mathrm{bB}}$ & $1.02^{\mathrm{aA}}$ & $2.42^{\mathrm{aA}}$ \\
\hline & T3 & Glazing & $6.67^{\mathrm{aA}}$ & $0.29^{\mathrm{aA}}$ & $1.04^{\mathrm{bA}}$ & $2.26^{\mathrm{aA}}$ \\
\hline & T3 & Chitosan & $6.37^{\mathrm{aA}}$ & $0.28^{\mathrm{aA}}$ & $1.01^{\mathrm{aB}}$ & $1.80^{\mathrm{aA}}$ \\
\hline
\end{tabular}


regarding the texture parameter, with negligible differences between coatings.

\section{Conclusions}

Microbiological analysis showed that the chitosan offered an anti-microbiological protection when compared with the water glazed samples, with much lower values of the microorganism's counts for the chitosan coated samples. It was also possible to observe a reduction in the TVC values during the assessment period within the chitosan coated samples. Regarding the TVB-N values neither the time of assessment nor the type of coating had a significant impact on the results being all values below the defined limits.

Textural analysis showed no significant differences between water glazed and chitosan coated samples, in all parameters assessed. Sensory analysis conducted by judges allows to conclude that the use of chitosan did not negatively influence the frozen, thawed and cooked coated samples, while in some parameters, such as appearance and color, its presence was beneficial. The flavor parameter was observed with special interest, as it is the one that can provide the most important information about whether a flavor diffusion had or not occurred, and results show that no significant differences in flavor occurred between chitosan coated and water glazed samples, leading to the conclusion that no flavor diffusion from the chitosan coating was present in the assessed samples.

While chitosan itself will not diffuse from the coating, smaller molecules will possibly be able to do so, creating an opportunity to use chitosan coatings as encapsulation matrices of flavors that can add value to the product, besides the microbiological protection already offered and demonstrated here.

\section{Acknowledgements}

The contribution of VANIBRU, Lda. regarding the PhD scholarship of Nuno Soares and the use of industrial facilities are gratefully acknowledged.

\section{References}

Casas, C., Martinez, O., Guillen, M.D., Pin, C., Salmeron, J., 2006. Textural properties of raw Atlantic salmon (Salmo salar) at three points along the fillet, determined by different methods. Food Control 17 (7), 511-515. http://dx.doi.org/10.1016/ j.foodcont.2005.02.013.

Castro, S.P.M., Paulín, E.G.L., 2012. Is chitosan a new panacea? Areas Appl. 3-46. http://dx.doi.org/10.5772/51200.

Chen, Y.L., 2008. Preparation and Characterization of Water-soluble Chitosan Gel for Skin Hydration. Universiti Sains Malaysia.

FAO, 2014. The State of World Fisheries and Aquaculture 2014. Rome. Retrieved from: http://www.fao.org/3/d1eaa9a1-5a71-4e42-86c0-f2111f07de16/i3720e. pdf.

Gonçalves, A.A., Gindri, C.S.G., 2009. The effect of glaze uptake on storage quality of frozen shrimp. J. Food Eng. 90 (2), 285-290. http://dx.doi.org/10.1016/ j.jfoodeng.2008.06.038.

González-Méndez, N.F., Alemán-Escobedo, J.F., Zamorano-García, L., Camou-
Arriola, J.P., 2004. Frozen muscle foods: principles, quality, and shelf life. In: Handbook of Frozen Foods. Marcel Dekker Inc, New York.

Hultmann, L., Rustad, T., 2004. Iced storage of Atlantic salmon (Salmo salar) - effects on endogenous enzymes and their impact on muscle proteins and texture. Food Chem. 87 (1), 31-41. http://dx.doi.org/10.1016/j.foodchem.2003.10.013.

Huss, H., 1995. Quality and Quality Changes in Fresh Fish. FAO Fisheries Technical Paper. FAO, Rome. Retrieved from: http://www.cabdirect.org/abstracts/ 19961402231.html.

International Commission on Microbiological Specifications for Foods, 1986. Microorganisms in Foods 2. Sampling for Microbiological Analysis: Principles and Specific Applications, second ed. Blackwell Scientific Publications. Retrieved from: http://www.icmsf.org/pdf/icmsf2.pdf.

IPQ 2009. NP 2930:2009-Produtos da pesca e da aquicultura: Determinação do teor de azoto básico volátil total (ABVT); Método de Conway; Pub. L. No. NP 2930: 2009. Costa Caparica, Portugal. Retrieved from: http://www1.ipq.pt/PT/site/ clientes/pages/Norma.aspx?docId=IPODOC-185-149630.

ISO. ISO 4833-1:2013. (ISO, Ed.), Pub. L. No. ISO 4833-1:2013, 2013. Retrieved from: http://www.iso.org/iso/catalogue_detail.htm?csnumber=53728.

Kim, S.-K., 2014. Chitin and chitosan derivatives: advances in drug discovery and developments. In: Kim, S.-K. (Ed.), Chitin and Chitosan Derivatives: Advances in Drug Discovery and Developments. CRC Press.

Lawless, H.T., Heymann, H., 2010. Sensory Evaluation of Food. Springer New York, New York, NY. http://dx.doi.org/10.1007/978-1-4419-6488-5.

Martinez, O., Salmerón, J., Guillén, M.D., Casas, C., 2007. Textural and physicochemical changes in salmon (Salmo salar) treated with commercial liquid smoke flavourings. Food Chem. 100 (2), 498-503. http://dx.doi.org/10.1016 j.foodchem.2005.09.071.

Nielsen, J., Jessen, F., 2007. Quality of frozen fish. In: Handbook of Meat, Poultry and Seafood Quality. Blackwell Publishing, Iowa, USA.

Official Journal of the European Communities, 1995. COMMISSION DECISION of 8 March 1995 fixing the total volatile basic nitrogen ( TVB-N) limit values for certain categories of fishery products and specifying the analysis methods to be used. Off. J. Eur. Commun. Retrieved from: http://eur-lex.europa.eu/legalcontent/EN/TXT/PDF/?uri=CELEX:31995D0149\&from=EN

Olafsdóttir, G., Martinsdóttir, E., Oehlenschläger, J., Dalgaard, P., Jensen, B. Undeland, I., Nilsen, H., 1997. Methods to evaluate fish freshness in research and industry. Trends Food Sci. Technol. 8 (8), 258-265. http://dx.doi.org/10.1016/ S0924-2244(97)01049-2.

Pascall, M., Lin, S.-J., 2012. The application of edible polymeric films and coatings in the food industry. J. Food Process. Technol. 04 (2) http://dx.doi.org/10.4172 2157-7110.1000e116.

Raafat, D., Sahl, H.G., 2009. Chitosan and its antimicrobial potential - a critical literature survey. Microb. Biotechnol. 2 (2 SPEC. ISS.), 186-201. http:// dx.doi.org/10.1111/j.1751-7915.2008.00080.x.

Rabea, E.I., Badawy, M.E.T., Stevens, C.V., Smagghe, G., Steurbaut, W., 2003. Chitosan as antimicrobial agent: applications and mode of action. Biomacromolecules 4 (6), 1457-1465. http://dx.doi.org/10.1021/bm034130m.

Singh, V., Kumari, K., 2012. Some physicochemical measurements of chitosan/starch polymers in acetic acid-water mixtures. Macromol. Symp. 320 (1), 81-86. http://dx.doi.org/10.1002/masy.201251011.

Soares, N.M., Fernandes, T.A., Vicente, A.A., 2016. Effect of variables on the thickness of an edible coating applied on frozen fish - establishment of the concept of safe dipping time. J. Food Eng. 171, 111-118. http://dx.doi.org/10.1016/ j.jfoodeng.2015.10.016.

Soares, N.M., Oliveira, M.S.G., Vicente, A.A., 2015. Effects of glazing and chitosanbased coating application on frozen salmon preservation during six-month storage in industrial freezing chambers. LWT - Food Sci. Technol. 61 (2), 524-531. http://dx.doi.org/10.1016/j.lwt.2014.12.009.

Texture Technologies Corporation, 2015. An Overview of Texture Profile Analysis. Retrieved July 6, 2015, from. http://texturetechnologies.com/texture-profileanalysis/texture-profile-analysis.php\#section-04.

Zoldos, P., Popelka, P., Marcincak, S., Nagy, J., Mesarcová, L., Pipová, M., Malá, P., 2011. The effect of glaze on the quality of frozen stored Alaska pollack (Theragra chalcogramma) fillets under stable and unstable conditions. Acta Veterinaria 80, 299-304. Retrieved from: http://actavet.vfu.cz/media/pdf/avb_ 2011080030299.pdf. 